\title{
Education Model for Abandoned Children \\ Phenomenology Study in West Nusa Tenggara Indonesia
}

\author{
I Nyoman Wijana \\ STAH Negeri Gde Pudja Mataram, Jalan Pancaka No. 7 B, Mataram 83126, Indonesia
}

Tel: 62-370-628-382 E-mail: wijanainyoman11@gmail.com

Received: March 11, 2015 Accepted: April 15, 2015 Published: April 16, 2015

doi:10.5296/elr.v1i1.7446 URL: http://dx.doi.org/10.5296/elr.v1i1.7446

\begin{abstract}
This research aimed at exploring, constructing, elaborating and describing one of social realities occurring in west Nusa Tenggara, Indonesia, namely education model for abandoned children. This research employed qualitative approach by using phenomenology method. The finding has shown that the education model implemented for abandoned children is a semi-orphanage model instead of an orphanage one theoretically. This research recommended the idea of a family-based education model in order that not only do the children obtain education access facilitated by government but also they keep getting affection from their families as an essential need for their growth.
\end{abstract}

Keywords: education model, abandoned children

\section{Introduction}

Poverty and ignorance is a phenomenon on some developing countries including Indonesia. The government of Indonesia has made various efforts to address the problem of poverty such as the direct cash assistance, the eradication of illiteracy and others. He believed that the efforts of very useful for the poor even though has not been effective, because it is still partial and have not been able to solve the root of the problem.

The fact emperis the point that, poor people is one factor causes of the under-served children in Indonesia particularly in the West Nusa Tenggara. The number of abandoned children reached 201.699 people who scattered in ten regencies/cities. (Bureau of Statistic \& BAPPEDA NTB Province, 2011). That increasing number of abandoned children must lead crucial problem for province, if not finding solution immediately. To apprehend the condition of increasing number of abandoned children and education access for them, the study needs to be done thoroughly. It is about not only how to provide education access but also how to provide the best model for their education. One of the possible ways to cut down the heritance of marginal class for next generation is by develoving education model for the 
children, which Tilaar supports the idea that education has the nature of human freedom. (Tilaar, 2009).

The relevant research was conducted by Sumarno et al. (2004) about the handling model of kinship-based model (close communion model) for abandoned children in 6 research locations; west Sumatra, south Sulawesi, west Nusa Tenggara, Bali, west Kalimantan and Yogyakarta. The research revealed that several kinship groups have been established in a few locations through social gathering, religious activity, social activity and donation for community. However, activity-focusing service for abandoned children has not programmed yet. It can be concluded that concept of abandoned children is unfortunate children who physical, psychological, and social needs are not fulfilled adequately yet. Whereas, community understanding to build kinship in local level is somewhat positive. This kind of thing has great potential to cope with abandoned children problem. It is also recommended that one of the strategies to tackle such problem be by kinship system (Sumarno, 2004).

Other research about social right of abandoned children whose theme "Potret Remaja Terlantar pada Panti Sosial Bina Remaja" (the portrait of abandoned teenage in Bina Remaja Social Institution) was conducted by Nurdin Widodo (2010). It is inferred that the causes of abandoned children are vulnerable kinship family bond, lack of community support, narrow perspective and working skill, and poverty effect. If those factors have reached culmination points: more strengthened poverty, weak and loose social control, increasing fragile social family, and unreachable education cost, the number of abandoned children will increase more (Widodo, 2010).

A study of need service for street children is a theme research conducted by Mujiyadi et al. (2011) in several provinces such as Lampung, west Java, central Java. East Java, and west Nusa Tenggara. The conclusion is that street children are a part of abandoned children whorequisite basic needs consisting physical, psychological, social and spiritual need. Some urgent needs to be fulfilled are food, clothing, house and health. At the same time they have right to obtain education access as well. Based upon the research finding, it also brings a hope for street children that basically their existence need to be acknowledged, they can run their life normally, continue their education to higher education, and enable them to find an outlet for their hobbies accordance with their talents and skills (Mujiyadi, 2011). The conclusions are obviously clear that the problems of abandoned and street children might become indicator of not fulfilling their social right, including education field. Thus, this thing needs to be studied empirically about the expansion and equality of education access for abandoned children.

Empiric data showed that the number of abandoned children tended to get increased quantitatively in west Nusa Tenggara every single year (Bureau of Statistic \& BAPPEDA NTB Province, 2011). This fact is as indicator that the implementation of education model for abandoned children is not effective to cut their reproduction. Thus, this research has a purpose to construct and describe education model of abandoned children in west Nusa Tenggara.

\section{Method}

This is a qualitative research by employing phenomonology approach. For data collection, 
this research relied on interviews, observation and documentary analysis. Abandoned children, social department for population and civil registration officer, education department for youth and sports officer, a head of orphanage Harapan Mataram, social workers, teachers for abandoned children were informants. Observation was conducted by taking part directly for 3 months in the orphanage, such as sport activity, cleaning activity and cooking activity for girls as well as tentative religious activity. Documents taken from orphanage, Bureau of Statistic and social department for population and civil registration of NTB Province were analyzed.

The informants as source data were done purposively to obtain data from key, primary and additional informants. The key informant is the head of orphanage since he is the most responsible person and knows a lot about educational service for abandoned children in west Nusa Tenggara. Primary informants are the officer from social department for population and civil registration, education department for youth and sports officer, and abandoned children who get education access funded from government. Additional informants are school teachers, children's parents or families and social workers. The instruments of collecting data are the researcher, recorder, and camera. Interviews were done in relaxed atmosphere informally. The research questions are about the expansion and equality of educational access for abandoned children in west Nusa Tenggara. The answers were recorded and noted down and analyzed based on relevant theories and relevant previous research findings. To avoid suspicious feeling from the children, observation was done in orphanage simultaneously to maintain the relationship with the children. The report research was written in narrative account.

\section{Results}

The present model for handling abandoned children generally has been categorized in two service models: orphanage model and non-orphanage model. In the context of this research, model managed by Harapan mataram orphanage is semi-orphanage model since the children stay in orphanage and go to formal schools. The orphanage provides basic need for children such as food, uniforms, clothes, transport cost, books, private additional lessons and many more. Yet, the abandoned children go to the same school with the same mechanism and requirement, which is also for other children. Abandoned children who are educated in orphanage go to formal schools that are located in Mataram under Education Department for Youth and Sports. This is to explain that the children from all levels, primary and secondary level go to formal schools instead of going to school in orphanage. It means that the implementation of education model is not orphanage one totally.

The data of abandoned children in several formal schools have shown that orphanage is only for their residence, while the education is taken place at formal schools. Based upon observation, documentary analysis and interviews, it can be described that the education model for abandoned children in west Nusa Tenggara is semi-orphanage model. If they implement orphanage model, all children's activities must be conducted in orphanage. This kind of thing has not occurred in west Nusa Tenggara.

The education for abandoned children is taken place inside and outside of the Harapan Mataram orphanage. It includes activities such as religion lectures, social guidance and skills (sports, cooking, learning how to operate computer, to learn music and faith and religious devotion), as well as additional private lessons (math, English, talent and art, counseling and 
entrepreneurship). Whereas the outside activity includes all learning process at schools, and working skill guidance for those who graduate from high school. This guidance has cooperation with other institutions, like training center and AMIKOM (information management and computer academy). The training has aimed to train the graduates to become independent so they can work and continue their life outside the orphanage as it is described in following figure.

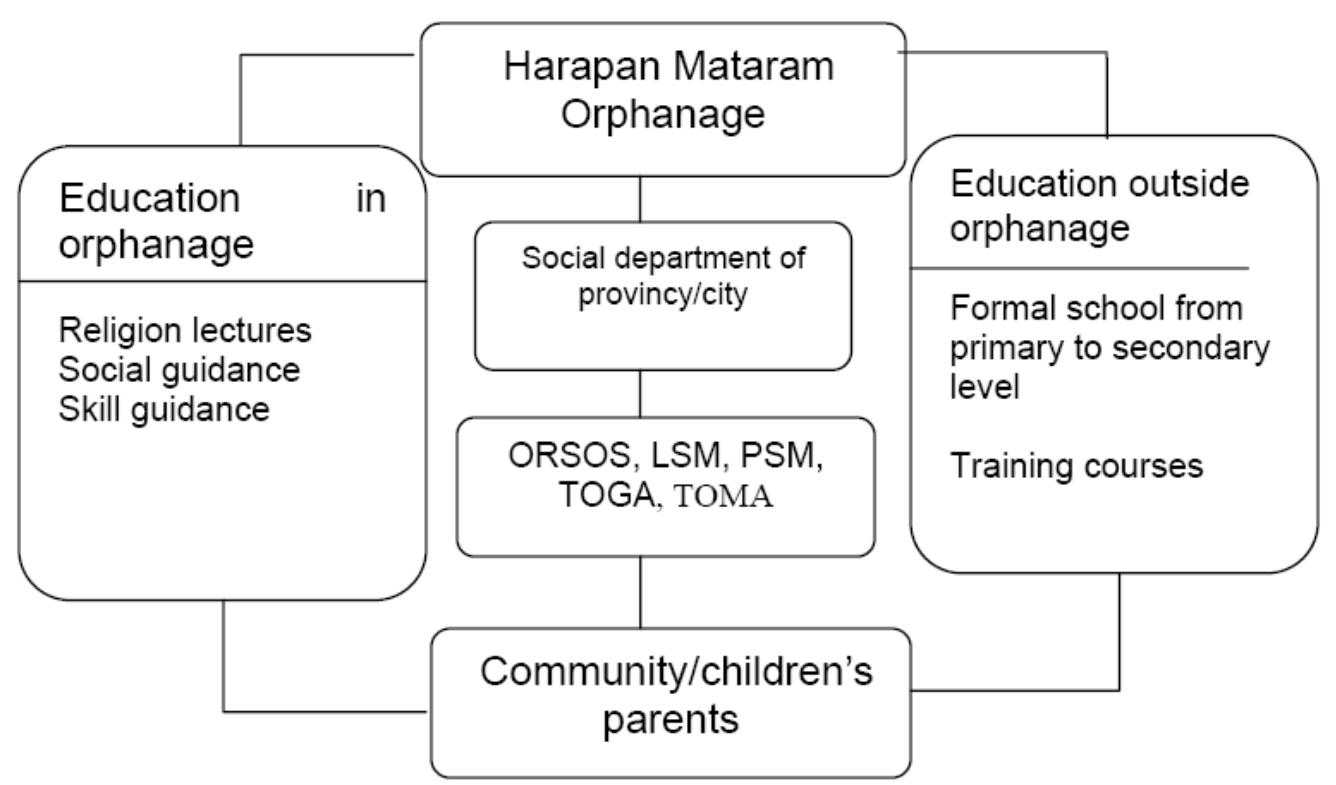

Figure 1. Education model for abandoned children at Harapan Mataram orphanage, west Nusa Tenggara

Source: Harapan Mataram Orphanage.

The head of orphanage informs social department of regency/city in west Nusa Tenggara about the children who will get education. To respond the information, social department has cooperation with social organizations, self-help community organizations, social workers, religion public figures, and public figures to collect data about abandoned children in their own districts. The data from all parties are verified and selected by team and home visit too. For those who fulfill and pass the requirement will be accommodated in orphanage and sent to formal schools. They will stay in orphanage until they graduate from high schools. After high school, they get training in training center or training course accordance with their interests and talents for 3 months before returning back to their families.

Education model for abandoned children constructed as semi orphanage model is also stated implicitly by some sources when doing the interview. A functional social worker explained that service model has been applied so far is known as an orphanage and non-orphanage model. An orphanage model is actually the last choice for government in handling abandoned children, when non-orphanage model is unlikely to be implemented. A few informants also said the same thing that service for abandoned children is given through basic need 
fulfillment such as food, clothing, health, affection and education access. They also added that there would be a family-based service in the near future. Thus, the children will remain in their family upbringing or their foster parents in order that they get affection from their families. Government gives direct donation to the family so that the children have the opportunity to obtain educational access.

The head of rehabilitation and social welfare service under social department for population and civil registration of west Nusa Tenggara province informed implicitly that abandoned children education has been implemented by the province is not an orphanage model as a whole based on the concept. It is because orphanage and non-orphanage institution that is formal schools and training courses apply the service.

The basic and affection needs are essential aspects that become government concerns for abandoned children. That's why, the idea of a family-based model as development model service for those children is somewhat exciting in the future.

\section{Discussion}

The current established model for abandoned children is categorized into two service models: orphanage model and non-orphanage model (Setyo, 2004). In this research, education for abandoned children managed by Harapan Mataram orphanage implements orphanage and non-orphanage model. The implementation of orphanage model is that all children stay and get education at orphanage. In addition, they also get basic needs. While the implementation of non-orphanage model is that all children go to formal schools. Beside that they are also trained and educated at training courses such as computer training, workshop and entrepreneurship in training center.

Data taken from several schools showed that orphanage is a place for their lodging, while education access is held at formal schools. Based on observation, documentary analysis and interviews, it can be described that education model implemented in west Nusa Tenggara is a semi-orphanage model since all learning processes and activities are held inside and outside of orphanage. As it is as well implemented in Harapan Mataram orphanage.

Educational model for abandoned children implemented in west Nusa Tenggara could be comprehended deeply from social theory perspective, particularly rational choice theory by Raymond Boudon. It is explained that there are a few principles underlying the theory of rationality. The first principle is to explain social phenomena as a cause or consequence from a set of statement that must be accepted easily. Second principle, good sociology theory is a theory that understands all social phenomena as the result of individual acts. Third principle is that all acts must be analyzed as rational act (Bryan, 2012).

Rational choice theory can put in plain words educational model for abandoned children. In line with first principle is that semi-orphanage model is a rational choice that explains social phenomena and can be easily accepted. This kind of model is implemented because of lack of resources, which support learning process in orphanage. In addition, the orphanage is not established to provide formal education service, but to give service for children who experience social problems. It is because formal education is under the authority of education and culture department whereas social service is under social department authority. By such rational explanation, alternative model of semi orphanage model is easily accepted. 
Education for abandoned children is a social phenomenon in west Nusa Tenggara as a result of individual acts of some parties including governor, the head of social department for population and civil registration, the head of orphanage and stakeholders who are interested in abandoned children education. The choice of semi-orphanage model is as consequence of individual acts that has been analyzed rationally. For instance, if the choice is an orphanage model, there will be overlapping tasks, especially between social department and education department. For the meantime, if the activities are executed outside the orphanage, there must be preparation for the implemented model that needs to be examined thoroughly. Even there is a more interesting idea for abandoned children in the future; existing process is definitely considered as rational alternative choice before the emergence of next rational choice and the readiness of its implementation.

\section{Conclusion}

Educational model implemented in west Nusa Tenggara province is a semi-orphanage model since not all activities are conducted inside the orphanage. This model has a positive impact to children quality because they are able to go to good schools funded by government and at the same time they can stay in an orphanage.

Ambiguous educational model can be meant that government is not serious to solve abandoned children problem. Since the budget has already been allocated, the government uses it to fund the project to inform that there is a project done. The project itself does not solve the basic problem if there is lack of seriousness.

Last but not least, in line with educational model for abandoned children, a family- based education model must become first priority, while an orphanage model must become the last alternative, particularly if family protection doesn't exist. Conceptually, a family-based education model is more humane compared to an orphanage model for the reason that the family is able to give more attention, affection and teaching values.

\section{References}

Abbas, S. (2009). Manajemen Perguruan Tinggi. Jakarta: Kencana Prenada Media Group.

Adi, R. (1994). Psikologi Pekerjaan Sosial dan Ilmu Kesejahteraan Sosial. Jakarta: Raja Grafindo Persada, Jakarta.

Bocock, R., \& Penerjemah, I. M. (1986). Pengantar Komprehensif Untuk Memahami Hegemoni. Yogyakarta: Jalasutra.

Bryan, S. T. (2012). Teori Sosial Dari Klasik Sampai Postmodern. Yogyakarta: Pustaka Pelajar.

Bourdieu, P. (2009). Habitus, Modal dan Ranah. Pengantar Paling Komprehensif Kepada Pemikiran Pierre Bourdieu, Bandung: Jalasutra.

Creswell, J. W. (2007). Qualitative Inquiri \& Research Design. London: Sage Publication.

Cohn, E. (1979). The Economic of Education. The United State of Amerika: Ballinger Publishing Company.

Dinas, S. P. L. (2011). Pengertian dan Karakteristik Penyandang Masalah Kesejahteraan Sosial. Retrieved from http://dinsoslampung.web.id

Fakih, M. (2003). Analisis Gender dan Transformasi Sosial. Yogyakarta: Pustaka Pelajar. 
Fatony, A. (2011). Kebijakan Pengentasan Kemiskinan Berbasis Participatory Poverty Asessment: Kasus Yogyakarta. Jakarta: Sosiokonsepsia Jurnal Penelitian dan Pengembangan Kesejahteraan Sosial, 16(2).

Foucault, M., \& Penerjemeh, Y. S. (2002). Wacana Kuasa Pengetahuan. Yogyakarta: Bentang Budaya.

Freire, P. (2008). Pendidikan Kaum Tertindas. Jakarta: Pustaka LP3ES Indonesia.

Hanifah, A. S. (2010). Kondisi Sosial Ekonomi Keluarga Pasca Pemutusan Hubungan Kerja. Jakarta: Jurnal Penelitian dan Pengembangan Kesejahteraan Sosial, 15(3).

Haryatmoko. (2001). Menyingkap Kepalsuan Budaya Penguasa. Jakarta: Basis.

Indrajit, R. E., \& Djokopranoto, R. (2006). Manajemen Perguruan Tinggi Modern. Yogyakarta: CV. Andi Offset.

Kuswarno, E. (2009). Fenomenologi, Konsepsi Pedoman dan Contoh Penelitian. Bandung: Widya Padjadjaran.

Mahfud, C. (2009). 39 Tokoh Sosiologi Politik Dunia. Surabaya: Jaring Pena Lini Penerbitan JP Books.

Moleong, L. J. (2007). Metodologi Penelitian Kualitatif. Bandung: PT. Remaja Rosdakarya.

Raco, J. R., \& Tanod, R. R. H. M. (2012). Metode Fenomenologi Aflikasi Pada Entrepreneurship. Jakarta: PT. Grasindo.

Robbins, S. P., \& Mary, C. (2012). Management, Global Edition. England: Pearson Education Limited.

Schermerhorn, J. R. (2010). Introduction to Management. USA: John Wiley \& Sons Inc.

Stake, R. E. (2010). Qualitative Research, Studying How Things Work. New York: The Guilford Press.

Sumarno, S. (2004). Model Penanganan Anak Terlantar Berbasis Kekerabatan. Jakarta: Puslitbang UKS-Balitbang Sosial-Departemen Sosial.

Tilaar, H. A. R. (2009). Kekuasaan dan Pendidikan, Manajemen Pendidikan Nasional Dalam Pusaran Kekuasaan. Jakarta: PT. Rineka Cipta.

Usman, H. (2010). Manajemen Teori Praktik dan Riset Pendidikan Jakarta: Bumi Aksara.

Winarno, B. (2011). Isu-Isu Global Kontemporer. Yogyakarta: CAPS.

\section{Copyright Disclaimer}

Copyright reserved by the author(s).

This article is an open-access article distributed under the terms and conditions of the Creative Commons Attribution license (http://creativecommons.org/licenses/by/3.0/). 